\title{
Complicity and Responsibility in the Aftermath of the Pinochet Regime: The Case of El Mocito
}

Michael J. LAzZARA

University of California, Davis

A slender 2005 volume published in Chile, Represión en dictadura: el papel de los civiles, announced a theme that until then (and after) has only garnered sporadic academic attention: the role of civilian accomplices in installing and upholding the Pinochet regime and its ideology ${ }^{1}$. This article stems from a conviction that civilian complicity is an area that has been generally understated in Chile's memory narrative and that its scope and the mechanics of its operation (in political, social, and narrative terms) deserve to be probed more deeply ${ }^{2}$. Complicity is, of course, readily identifiable in Chile today. It manifests in myriad figures ranging from repressors like Cristián Labbé, a former military officer and secret police agent who, wearing civilian clothes, until recently preached pinochetismo from his position as mayor of one of Santiago's elite neighborhoods, to conservative presidential candidates and government ministers like Pablo Longueira, Andrés Chadwick, or Joaquín Lavín, who tend to downplay that in 1977 they pledged eternal loyalty to General Pinochet in a fascist-cult-like ceremony on Chacarillas hill ${ }^{3}$. We also see it in figures like journalist Hermógenes Pérez de Arce, who from his sacred post as a columnist for El Mercurio (Chile's main daily paper) continues to rail against the vilified "Marxists", even in the context of today's student protest movement, or in prominent, economically powerful families like the Kasts or the Mattes whose links to the dictatorship's violence have recently been confirmed in journalist Javier Rebolledo's groundbreaking work A la sombra de los cuervos: los cómplices civiles de la dictadura (2015) ${ }^{4}$. The list could go on and on.

Political scientist Felipe Agüero has noted, in fact, that civilian accomplices were critical to the consolidation and institutionalization of the Pinochet regime's reign of terror and neoliberal economic project. Nevertheless, during the transition these

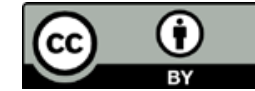

Article received at 27-1-2016 and accepted for publication at 22-6-2016.

1. Fernando Villagrán, Felipe AgüEro, Manuel SAlazAr, and Manuel Délano, Represión en dictadura: el papel de los civiles, Santiago de Chile, LOM Ediciones, 2005.

2. On civilian complicity in the Chilean case, see Víctor OsORIO and Iván CABEZAS, Los hijos de Pinochet, Santiago de Chile, Planeta, 1995. For the Argentine case, see David M. K. SHEININ, Consent of the Damned: Ordinary Argentines in the Dirty War, Gainesville, University Press of Florida, 2012, and Horacio VERBITSKY and Juan Pablo BOHOSLAVSKY (eds.), Cuentas pendientes: los cómplices económicos de la dictadura, Buenos Aires, Siglo XXI Editores, 2013. For the South African case, see Mark SAnDERS, Complicities: The Intellectual and Apartheid, Durham, Duke University Press, 2002.

3. Cristián Labbé's role as an agent of Pinochet's secret police gained acute public visibility with the publication of journalist Javier REBOLLEDO's El despertar de los cuervos: Tejas Verdes, el origen del exterminio en Chile, Santiago de Chile, Ceibo Ediciones, 2013.

4. REBOLLEDO's book is the first in Chile to systematically assess the theme of civilian complicity with the dictatorship. REBOLLEDO studies two prominent massacres of peasants and workers that occurred in 1973: the cases of Paine and Laja. He goes to painstaking lengths to prove the intricate and sordid connections of the Kast and Matte families, respectively, to these emblematic cases. See Javier Rebolledo, A la sombra de los cuervos: los cómplices civiles de la dictadura, Santiago, Ceibo Ediciones, 2015. 
accomplices have consistently denied or sidestepped responsibility, preferring to bracket human rights as an issue seemingly disconnected from the country's miraculous economic transformation. Their narratives, often predictably reconciliatory in tone, or sometimes brazenly unrepentant, are discursive performances riddled with shame, excuses, half-truths, and blatant lies.

Starting from the general theme of civilian complicity, I want to focus here on the textual (or, what we might call, representational) negotiations that happen around it, on the ways in which complicit subjects account for themselves, as well as on the ways in which those who give public visibility to accomplices' stories frame their experience. In Unsettling Accounts: Neither Truth nor Reconciliation in Narratives of State Violence (2008), Leigh Payne astutely theorizes the performativity of confessional discourse in relation to overt repressors like the Chilean torturer Osvaldo Romo or former secret police chief Manuel Contreras ${ }^{5}$. She is keen to the dynamics of perpetrators who reinvent themselves through narrative and assert their voices on the public stage in ways that, according to her thesis, generate healthy debates and points of contention in transitional societies. But are these debates always healthy? Can the portrayal of certain voices (in certain ways) actually cause harm? What risks are inherent in letting accomplices speak, or in placing them center-stage and framing them through particular lenses?

Forty years after the September 11, 1973 military coup that installed the Pinochet regime and deposed Salvador Allende's democratically-elected Socialist government, the public archive of the dictatorship years (1973-1990) continues to evolve and expand. New details come to light, or old details that were shielded from the public eye, sometimes gain traction in new moments that make it possible for a society to suddenly hear what it couldn't before. At times, these new details spark a maelstrom that burgeons into a veritable phenomenon. Such was the case with a man known by Chileans as El Mocito.

In 2010, in a good example of what Alexander Wilde once called an "irruption of memory," a pathetic figure known as El Mocito (a term meaning, simply, the "young man" or the "young butler") burst onto the public scene, quickly agitating the fragile waters of Chile's postdictatorial memory saga. ${ }^{6}$ Jorgelino Vergara, one of the dictatorship's most lowly accomplices, was tasked in his adolescence with serving coffee to the head of Pinochet's secret police, General Manuel Contreras, as well as to Contreras's cronies; furthermore, he was asked to carry out tasks in several clandestine detention and torture centers, most notably in the torture center located at 8800 Simón Bolívar Street (in Santiago), a place of terror from which it is said that only one prisoner got out alive. As part of his abhorrent work, Vergara was tasked with packing prisoners' bodies and loading them into military planes to be thrown out to sea. Over the course of

5. Osvaldo Romo Mena was one of Chile's most notorious civilian torturers. His life and perspectives are studied in journalist Nancy GuZMÁN’s book Romo: confesiones de un torturador, Santiago, Planeta, 2000. General Manuel Contreras was the first head of DINA. Imprisoned for massive human rights violations, he died in August 2015. Leigh A. PAYNE studies the performative, confessional discourse of both of these men in Unsettling Accounts: Neither Truth Nor Reconciliation in Confessions of State Violence, Durham, Duke University Press, 2008.

6. Alexander WILDE, "Irruptions of Memory: Expressive Politics in Chile's Transition to Democracy", Journal of Latin American Studies 31/2 (May 1999) pp. 473-500. The noun "irruption” derives from the Spanish verb irrumpir and refers to the ways in which traumatic memory appears on the political and cultural scene in ways that are often sudden and unanticipated. 
twelve years (1974-1985), he served the dictatorial state first as part of DINA (Dirección de Inteligencia Nacional, National Intelligence Directorate), while he was still a minor, and later as part of CNI (Central Nacional de Informaciones, National Intelligence Center), Pinochet's second secret police organization (essentially DINA by another name), when he was a full-fledged adult ${ }^{7}$. Wrongly accused in 2007, almost thirty-five years later, of having killed the famed Communist Party leader Víctor Díaz López, Jorgelino Vergara emerged from his clandestine and nomadic life-or, more aptly put, I should say that he was hunted down by detectives-only to testify soon thereafter before Judge Víctor Montiglio in an attempt to clear his name and avoid judicial reprisal. (A key detail: Had detectives never accused him of murder, it is likely that Vergara never would have talked or come out of hiding!) Because of his testimony in court, Chilean human rights organizations were able to confirm the existence of the, until then, unknown Simón Bolívar detention center, and seventy four former DINA and CNI agents were later convicted of crimes. Also, thanks to Vergara's testimony, the remains of four of the dictatorship's victims were found, thus allowing their families to bury tiny shards of bone that were dug up in the mountainous area outside Santiago known as Cuesta Barriga, and thus gain at least a semblance of closure, twenty-six years after the three communist militants disappeared ${ }^{8}$.

Throughout Chile's transition to democracy, it has not been the norm for perpetrators or those linked to them to break the military's long-established pact of silence. The 1995 Univisión interview with civilian torturer Osvaldo Romo Mena, which later became the basis for Nancy Guzman's book Romo: confesiones de un torturador (2000), or General Manuel Contreras's television interviews, are perhaps marked exceptions to the rule-although neither one of these men truly repented or revealed any information that human rights organizations did not already know. For many years, then, Chile could not boast a confession as significant as that of former Argentine naval captain Adolfo Francisco Scilingo, who declared on Argentine television in March 1995 that detained-and-disappeared had been drugged and thrown alive into the sea ${ }^{9}$. As Claudia Feld has shown, even when perpetrators like Scilingo are unrepentant, the weight of their words can produce unanticipated and often positive effects for societies in transition ${ }^{10}$. In the case of Scilingo, his "confession” generated renewed public interest in the "Dirty War" in a mid-1990s moment in which impunity reigned; it also created the conditions of possibility for the voices of human rights organizations to be heard and received more loudly by the Argentine people ${ }^{11}$. Although a similar testimony emerged in Chile in July 2003, it did not receive the media attention

7. DINA was the Pinochet regime's first secret police organization. It functioned from November 1973 until 1977, when it was replaced by CNI. Because the sole survivor of the Simón Bolívar detention center wishes to remain anonymous, he is not named in this article.

8. The four men whose remains were found are Ángel Guerrero (MIR, Movimiento de Izquierda Revolucionaria, Leftist Revolutionary Movement); Lincoyán Berríos (PC, Partido Comunista, Communist Party); Horacio Cepeda (PC); and Fernando Ortiz (PC).

9. See also, Horacio VerbiTSKy, El vuelo, Buenos Aires, Planeta, 1995.

10. Claudia FELD, "Entre la visibilidad y la justicia: los testimonios televisivos de represores en la Argentina”, Encuentros Uruguayos Año II/2 (November 2009), pp. 42-57.

11. Ibidem, p. 52 
that Scilingo's testimony did, nor did it produce lasting or memorable effects ${ }^{12}$. The case of Jorgelino Vergara is therefore that much more significant because it managed to create a noteworthy and sustained presence in the public eye, in particular thanks to Rebolledo's book and Said and De Certeau's film. Moreover, the proximity of Vergara's appearance on the national scene to the fortieth anniversary of the September 11, 1973 coup made it such that artists, journalists, and intellectuals took notice of him, not just judges and the police. As the country approached an anniversary of the coup that would blow open the Pandora's box of the past much wider than ever before, Chilean society finally seemed ready to opine about a lowly collaborator figure like Vergara whom the country's collective memory narratives had previously excluded.

This background brings me to my main question: How did Chileans configure a public archive of this entirely marginal figure (poor and impoverished), an accomplice to the horrors of dictatorship, a lackey in the apparatus of the dictatorial state who carried out appalling tasks from a servile position in the regime's hierarchy? What languages made it possible for Chileans to think about, debate, or even consume voyeuristically this character who belonged to what Primo Levi, in the context of the Holocaust, called the "gray zone" of complicity with dictatorial power? ${ }^{13}$

In the short expanse of two years (2010-2012), this character, El Mocito, appeared repeatedly before the public eye in a series of representational formats motivated by differing authorial intentions ${ }^{14}$. First, in 2010, a documentary film called El Mocito debuted. Its directors, Marcela Said and Jean De Certeau, set out to create an intimate, psychological portrait of Vergara as a "survivor" (Said's word) who, thirtyfive years later, still struggles to resolve his own personal shame and trauma. Said's film left much to the imagination given that its goal was not necessarily to portray the "facts" of the case, but rather to document Vergara's day-to-day existence and highlight the pathetic, idiosyncratic behaviors of a kind of strange specimen that the dictatorial state managed to produce. For Said, Vergara was an unfortunate man, a victim of his circumstances, a man to be pitied, and, consequently, her portrayal of him (quite

12. Following the 1999-2000 Mesa de Diálogo, the Chilean military recognized that some bodies of the disappeared had been thrown into the sea. However, no individual military official ever spoke publicly about how such missions were carried out. This changed on July 7, 2003 when a retired soldier, Subofficial Juan Carlos Molina H., testified on Televisión Nacional's nightly news program 24 Horas that he had participated in two missions in 1979 to dispose of the bodies of nine desaparecidos. In his interview with reporter Claudio Fariña, Molina admitted having witnessed the dumping of bodies from Puma helicopters into waters off the coast of Quintero. This type of disposal of bodies, which according to Molina continued to occur until at least 1981, was a reaction by the military to the 1978 discovery (and subsequent publicity) of a common grave located at Lonquén, outside Santiago. The military's fear of future discoveries caused them to dig up victims' remains and to dispose of them in undisclosed locations. Molina, a mechanic asked to provide technical support for helicopters, told Fariña that the bodies were placed in sacks and bound to railroad ties so that they would sink in the ocean. Though for years he could not admit what he witnessed, the death of his child in 2003 prompted him to come forward and voice his shame publicly. TVN's report was an important public revelation of the official silences that had surrounded such missions for thirty years. Unlike the case of Scilingo in Argentina, however, Molina's confession did not prompt other military officials to come forward.

13. Primo LeVI, The Drowned and the Saved, New York, Vintage International, 1988, pp. 36-69. LEVI is particularly interested in "the network of human relationships inside the Lagers [... that] could not be reduced to the two blocs of victims and perpetrators” (p. 37).

14. I would like to note that throughout this article I use the term "Mocito" sparingly to refer to Vergara as a framed and constructed character. In most cases, I prefer to call him by his proper name, Jorgelino Vergara, so as not to lose sight of the fact that he is a real, biographical subject. 
generous, I think, on balance) sought to elicit sympathy in the viewer. Said's film purposefully took distance from what Vergara did (or did not do) and instead turned him into a character, one, I would add, that she dangerously divests of both agency and ideology.

Following the premier of El Mocito, a book appeared on the scene, penned by a young journalist, Javier Rebolledo, who had worked with Said as an investigator during the process of filming her documentary. Unsatisfied on some level with the film's artistic approach to the character, Rebolledo, as any good journalist would, set out to create a detailed accounting of the facts of Vergara's case, which was later published in the form of a best-selling book called La danza de los cuervos (2012). The book, which to date has had three editions and sold around fifteen thousand copies, brought the Chilean public face-to-face with an accomplice, providing a much more balanced view of Vergara's case and resisting the temptation to pass judgment on him morally. Judgment, in the case of Rebolledo's book, is left to the reader who can assess Vergara's narrative and form opinions according to the evidence.

Finally, following the publication of Rebolledo's book, Vergara appeared yet a third time before the public eye (in July 2012), this time as an interviewee on journalist Tomás Mosciatti's evening television program La Entrevista on CNN-Chile. This journalistic montage was, in a word, offensive. Not only did it treat and represent Vergara abusively, capitalizing on the spectacular nature of his marginality, it also sensationalized violence and torture in a way that was equally off-putting.

I am interested in this multi-genre archive of El Mocito: a film, a book, and a television interview, all quite different in their framings, uses, and even abuses of the character. My goal is to reflect on the nature and ethical consequences of these three representations of the accomplice. I do this fully recognizing how delicate a matter it is to evaluate materials such as these, particularly because all have undeniably triggered positive effects in Chilean society. Because of Vergara's testimony, as I have mentioned, there are perpetrators in jail, and Chilean society has deepened its understanding of yet another aspect of the multilayered and secretive dictatorial state. Moreover, there are also family members who have gained a modicum of peace by burying their dead. However, despite these positive effects, we cannot shy away from our critical responsibility to approach these representations carefully and cautiously, wary of the nature of each one, and ready to condemn (as Nelly Richard suggests) the triviality of representations so crude and irresponsible that they run the risk of betraying the victims' memory ${ }^{15}$. It is my feeling that we shouldn’t let ourselves get carried away by the Mocito phenomenon, but rather seize upon this unusual irruption of memory to do a critical accounting and reflect, yet again, on the ethics of representing a past whose history is far from fully written.

\section{Humanizing the Accomplice: Marcela Said and Jean DeCerteau's EI Mocito (2010)}

From the very first moments of Marcela Said and Jean De Certeau's El Mocito, Jorgelino Vergara appears as a solitary, pathetic figure, a poor man, one of twelve siblings who found work by chance and out of dire necessity in the home of General Manuel Contreras. After working for years in the heart of the Pinochet regime's

15. Nelly RiCHARD, Crítica de la memoria (1990-2010), Santiago de Chile, Ediciones Universidad Diego Portales, 2010, p. 117. All translations from the Spanish throughout this article are my own. 
apparatus of terror, Vergara finds himself living clandestinely in the south of Chile, far from urban life and the reach of justice. Decades after leaving the DINA/CNI, the filmmakers track him down, follow him, and film him in a somewhat hyperbolic light as he goes about his daily routine. The man's poverty and abjection are noteworthy; he appears to the viewer as something of a rare bird. In a lengthy early sequence, Vergara is shown killing a rabbit in a cold and calculated way, a necessity for his subsistence. The filmmakers focus on how Vergara skins the creature and drains its blood. In other early sequences, we see the protagonist bathing in a river, refining his skill with nunchakus, as if he were Bruce Lee, and staring into space contemplatively. These sequences are meant to pique the viewer's interest in the protagonist's idiosyncrasies, compelling him to wonder how Vergara honed such a methodical capacity to kill, particularly considering that he has consistently denied having killed or tortured anyone while working for Pinochet's secret police.

To be fair, Said and DeCerteau do suggest certain ambiguities in their main character. They are interested, throughout the film, in exploring the fine line that separates the victim from the victimizer. They are attuned to the ambiguities in Vergara's discourse and they make it a point to highlight those ambiguities at certain points in the film. If at first the camera shots distance us from Vergara, treating him as somewhat grotesque or disturbed, later camera shots draw him closer to us, humanizing him. If we consider the whole film, it becomes possible to establish a narrative arc that takes us from distance and deformity to humanization and an acceptance of the accomplice as a victim of the dictatorship. As Marcela Said explained to me in a personal interview: "We can say that in some sense he was also a victim of his circumstances, of his lack of education, his poverty, his ignorance at the time, his naiveté when pretending to be a soldier because he thought it was fun.... He is an attractive character precisely because of his complexity" 16 . Therefore, even though Vergara is an accomplice to the dictatorship who is probably hiding certain important information, Said and De Certeau maintain that he is, above all, a traumatized man who should be given the opportunity to tell his story, to understand it more deeply and, even more importantly, to heal. They argue that Vergara has tried valiantly to remake his life and do what is ethically correct. In short, he has gone from being a collaborator with state repression to becoming what he is at present: in Said's words, "a collaborator with justice” ${ }^{\prime 17}$.

Said and De Certeau's film was selected by Chile's National Human Rights Institute (Instituto Nacional de Derechos Humanos) as one of a number of documentaries that can be used "informally" for educational purposes. This is significant because the curriculum about the dictatorship in Chilean's primary and secondary schools is still quite basic and lacking in complexity. To help teachers spark classroom debates about the film, Marina Lotero Donoso Rivas, in consultation with the directors, prepared a packet of pedagogical materials that contains activities, discussion questions, and suggestions for debate ${ }^{18}$. Somewhat predictably, the materials echo the

16. Michael J. LAZZARA, "Radiografía del pinochetismo: una conversación con la documentalista Marcela Said,” Chasqui: revista de literatura latinoamericana, 42/1 (2013), p. 254.

17. Ibidem, p. 252.

18. See Marina Loreto Donoso RIVAS et al., El Mocito: un documental de Marcela Said y Jean de Certeau, Serie Recordar y Conversar para un Nunca Más, Documentales para la memoria histórica de violaciones masivas y sistemáticas de Derechos Humanos, Santiago de Chile, Instituto Nacional de Derechos Humanos, n. d., <http://www.indh.cl/descarga-de-material>. 
directors' focus on the ambiguous nature of Vergara's actions, on his "fluctuation between [the categories of] victim and victimizer." The materials summarize the film's thesis statement as follows: "[The Pinochet regime espoused a] politics of recruiting vulnerable people to participate directly or indirectly in the dictatorship's crimes. In this context, the film proposes that people like Jorgelino are but one more consequence of State Terrorism." Discussion activities compel teachers and students to think about Vergara in relation to concepts like "memory," "forgiveness," "truth," and "reparation," or to select three words that best describe Vergara from the following field of choices: "marginal," “astute,” “strong," "accomplice,” "assassin,” "traitor,” “charlatan,” "repentant," and "victim." Another activity asks students to subject Vergara to a mock trial in which two students play the role of prosecutors, two play the role of defendants, and several play the role of judges. Toward the end of the packet, a final activity asks students to consider the film's overall progression - that is, Vergara's journey from the "inferno" to "purgatory" to "redemption"-and to decide if such a characterization of the film's narrative arc is accurate or appropriate. It is worth noting, therefore, that the accompanying didactic materials, on the whole, echo the film's desire to portray Vergara as an ambiguous character who, as a vulnerable subject, moves along a path to redemption because of his willingness to testify in court and to meet directly with the family of a disappeared victim from the Simón Bolívar detention center. By asking questions and proposing activities that prime or lead students to acknowledge that Vergara is also a victim, the directors are able to reinforce pedagogically a humanized view of the collaborator that, in their opinion, avoids lapsing into Manichean visions of the past.

What I would like to emphasize, then, is how, on balance, the film provides a generous view of the accomplice that is meant to evoke sympathy, or empathy, on the spectator's part. This interpretive vision develops gradually, starting with the film's earliest sequences. When toward the beginning of the documentary Vergara is interviewed by one of Chile's most prominent human rights attorneys, Nelson Caucoto, the accomplice argues that he was an "involuntary actor" who "practically felt like one more prisoner." The conversation with Caucoto foregrounds Vergara's reading of himself as a victim and plants a seed that he can-and perhaps should-be read in this way. In later sequences, Vergara is no longer the only one affirming his victimhood; rather, other informants evoke pity for the accomplice by reading him as a victim from the outside. In one of these sequences, for example, Vergara appears seated at a table and remains silent while another man-his brother-in-law-speaks on his behalf. The brother-in-law notes that Vergara "was never the same" after joining DINA: "His memory is full of gaps that no one else can know; only he knows." All the while, Vergara remains there, entranced, drinking mate. Later in the film, others who knew Vergara testify that he joined the DINA out of economic need and that, while there, the regime "brainwashed him." These other voices in the film thematize what Dori Laub has called "empathic listeners," which Laub sees as vital to the survival of trauma victims $^{19}$. The inclusion of empathic listening within the film generates a cumulative effect that has the potential to influence the viewer and compel him to understand-and perhaps even forgive-Vergara's collaboration, his silences notwithstanding.

19. LAUB writes: "The absence of an empathic listener, or more radically, the absence of an addressable other, an other who can hear the anguish of one's memories and thus affirm and recognize their realness, annihilates the story." See Dori LAUB M.D., "Bearing Witness or the Vicissitudes of Listening," in Shoshanna FELMAN and Dori LAUB M.D. (eds.), Testimony: Crises of Witnessing in Literature, Psychoanalysis, and History, New York, Routledge, 1992, p. 68. 
The filmmakers' generous vision of the accomplice culminates in the film's closing sequence in which Vergara, having stared into the mirror at length, convinces himself that by telling the truth he is working to advance the cause of human rights. If at the beginning of the film, the aesthetic composition of the sequences seeks to show a destroyed, alienated, and very strange Vergara going about his daily routines — skinning rabbits, playing with nunchakus, and bathing in the river-the later sequences, like those in which Vergara participates in a religious parade or stares at himself in a mirror, appear to want to convince the viewer that Vergara is a reformed (or perhaps even a redeemed) man. Aesthetically, the progression from a strange and hyperbolic world to another that is clean-cut and austere reinforces the idea of redemption. The film's emphasis on Vergara's deepening faith in God, which corresponds to his biographical maturity, simply exacerbates this feeling. Standing in front of the mirror, Vergara shaves - he literally cleans up his physical appearance as an outward manifestation of the change that is occurring within him-and then mutters to himself: "You are the most important man on Earth[...]. I hope the rest of the world realizes what you're doing. You are doing something good for human rights, for human rights, for human rights.” The repetition serves to convince him. He appears fearful, but his pep talk gives him the courage to meet with one of the victims' families.

In the final sequence, Vergara then goes on to meet with the children of Daniel Palma, a communist militant who disappeared from the Simón Bolívar detention center in 1976. Two years before the encounter that takes place in the film, Vergara recognized a photograph of Palma that he was shown in court by Judge Víctor Montiglio. When Vergara sits down with the Palma children, the scene is dramatic. The children hope to find out who, specifically, tortured and killed their father. The attitude of Ricardo Palma, one of the sons, is noteworthy. He says he doesn't want drama, but rather peace, and this, he acknowledges, implies that both sides must make concessions. Palma is well aware that for Vergara to share what he knows, the family, too, has to be willing to sacrifice some justice for truth ${ }^{20}$. Vergara, doing his part, upholds his end of the bargain and reveals the names to the Palma family, writing them on a piece of paper. The scene is truly unique because, in the space of a film, we witness a dynamic that not even the 1999-2000 Mesa de Diálogo could achieve: a genuine, honest, and significant exchange between victims and victimizers ${ }^{21}$. The sequence seems to suggest that some kind of reconciliation is possible in Chile, if only victims and victimizers can set aside their anger in the interest of transparency and truth. The film, quite notably, then, ends on a reconciliatory note and casts the accomplice as reformed character who has found God and done what is right.

20. This idea echoes, to some extent, the logic of the South African Truth and Reconciliation Commission, whose final report was published in 1998. It also summarizes the long-held opinion of prominent Chilean human rights attorney José Zalaquett, who was an influential member of Chile’s 1990 National Commission on Truth and Reconciliation (or Rettig Commission). Zalaquett continues to favor the idea of trading impunity for truth.

21. The Mesa de Diálogo brought together representatives of the armed forces, the Catholic Church, the government, and other sectors of society with the purpose of discovering the whereabouts of the detainedand-disappeared. The initiative began during the presidency of Eduardo Frei Ruiz-Tagle and ended during the first year of Ricardo Lagos's presidency. At the conclusion of the roundtable, the military gave the family members a list containing information about two hundred disappeared people. It was later discovered that much of that information was false. The Mesa, therefore left many family members infuriated and mistrustful of the military and the government. They felt that the military's response was an affront to their pain and their decades-long search for truth and justice. 
Why Said and De Certeau decide to portray Vergara in this generous light is difficult to pinpoint with certainty. Any hypothesis falls squarely into the realm of speculation. However, it does seem relevant that Said, as she has revealed in interviews, comes from an upper class family in which several of her family members supported Pinochet $^{22}$. It is curious then, that the daughter of pinochetistas has dedicated almost the entirety of her cinematic production to date, which also includes her documentaries $I$ Love Pinochet (2001) and Opus Dei: una cruzada silenciosa (2006), to decoding the mentality of those ordinary people who supported Pinochet. We might say, then, that the main question behind her work is: Who are the pinochetistas, and what motivates their actions? In that vein, it is almost as if she is using her filmic project to explore her own biography, subjectivity, and lineage as a citizen and a daughter of the generation that lived through the coup and that, in many ways, inherited its violence without being directly responsible for it. If we accept this possibility, it is perhaps less surprising that her vision of Vergara is so generous and that she portrays him, on balance, as a reformed figure whose subjectivity is, as she says, "complex."

As is often the case in the cultural production of the children or descendants (either direct or indirect) of dictatorial violence, the one who has inherited a sordid and complex past often strives to take distance from it, "to defy it," but at the same time risks "mystifying" it in ways that can be self-serving ${ }^{23}$. In the case of Said, it is reasonable to assume, given the critical tenor of her films, that she is uncomfortable with her own inherited biography. An equestrian enthusiast, she has a direct connection, for example, to the head of the Lautaro Brigade of DINA, Juan Morales Salgado, who is now in prison and who appears as an informant in El Mocito: Morales, shockingly, was Said's riding teacher! Her personal link to this man makes it easier for her to access him and to convince him to testify in her film-though it is also true that he is already heading to prison at the time of filming and likely has little to lose by talking. Her biographical links to the world of pinochetismo, therefore, may help to explain why Said emphasizes the ambiguities of her main character rather than condemn him outright.

Furthermore, I find it compelling that Said's aesthetic, which takes distance from Vergara, as much as is brings him up close to us, encapsulates a broader trend that I see at work in Chilean filmmakers and writers whose productions emerge, like Said's, in the $2000 \mathrm{~s}^{24}$. These filmmakers readily employ a number of distancing mechanismssometimes irony, sometimes humor, satire, or parody - to mark a position of impotence, disagreement, or shame in the face of the actions of the Chilean state or of the generations who came before them. By using these distancing mechanisms, they seek to dis-identify with the Chile they have inherited. I am left, therefore, asking whether Said's humanized treatment of Vergara can be read as an attempt to grapple with her own familial and generational association with the world of pinochetismo-an association which, as an artist and person, she actively rejects, but from which she also cannot entirely escape. The discourse of reconciliation, from that perspective, might therefore pose a logical resolution to a complex and fraught problematic.

22. Marcela SAID, personal interview with the author, Santiago de Chile, September 2013.

23. Ana AmAdo, La imagen justa, Cine argentino y política (1980-2007), Buenos Aires, Colihue, 2009, p. 165.

24. As examples of this tendency, we can mention the projects of novelists like Alejandro Zambra and Nona Fernández, or the films of Bettina Perut and Iván Osnovkoff, among others. 


\section{A Portrait in Gray: Javier Rebolledo's La danza de los cuervos (2012)}

Like in Said and De Certeau’s film, Javier Rebolledo’s La danza de los cuervos paints a portrait of Jorgelino Vergara rooted in his humble origins (his poverty, his status as an orphan) in the southern Chilean city of Curicó. Yet unlike in the film, Rebolledo does not reference Vergara's impoverished background to offer excuses for the accomplice's behavior or to humanize him in a reconciliatory key. Instead, the journalist frames his main character as an example of what we might call popular fascism: a vulnerable and precarious subject who internalizes the discourse of dominant power-another "nomadic body," to quote an expression made popular by Chilean writer Diamela Eltit ${ }^{25}$.

Having only finished the third grade, Vergara, lacking formal education and stoked by his instinct to survive (although I should note that he also shows evidence of an alarming craving for upward mobility at any cost) seeks his education among the military. His military fantasies are striking, and Rebolledo draws this out in the text. Vergara wants to be one of them! He considers living in General Contreras's house a "luxury"26 and, in a relatively short time, begins to crave "professionalization" 27. Chapter sixteen of the book, titled "El bautizo del pajarito Nuevo" [The Young Foundling's Baptism], is key in this sense because it describes the initiation ritual required for Vergara's indoctrination in the male-dominated military world. As part of this ritual, he learns to drink alcohol and fire a gun. He even experiences a kind of sexual initiation; Rebolledo implies that Vergara sleeps with one of the female DINA agents at the end of a drunken bacchanal. The orphan, consequently, finds a family among the military: the soldiers educate him, program him, and transform them in their subordinate, in body and soul.

Nevertheless, if Vergara is for Rebolledo a vulnerable subject who is undeniably abused by the dictatorial state, Rebolledo is not willing to admit that Vergara lacks agency. The military world generates for Vergara a blinding attraction that Rebolledo acknowledges. Holding a weapon in his hand gives Vergara pleasure. At times he fantasizes that he is Rocky Balboa or Bruce Lee. He even learns to "hate" the enemy ${ }^{28}$. To perform the part of a military man, in some sense, winds up convincing Vergara of his actions. In short, the military world opens a space in which Vergara can gain a level of prestige and notoriety of which he could only dream-although we must fully recognize that he never ceases to be very marginal within that world, despite his delusions of grandeur. Yet, perhaps more importantly, being part of DINA also provides Vergara a semblance of financial stability, a minimal salary on which to subsist. His

25. In an article on the Nazi sympathies of Chilean writer Miguel Serrano, Diamela ELTIT defines "popular fascism" as follows: "Oppressed social groups [...] internalize all of the exclusionary tenets that emanate from society's dominant voices. They appropriate those discriminatory voices and use them against their peers and, consequently, they reproduce in their own social spheres identical hierarchies to the ones that impact them in their own lives. That is what popular fascism is" ("Hagamos memoria: cretinos filonazis," The Clinic Online, 10 April, 2012, <http://www.theclinic.cl/2012/04/10/hagamosmemoria-cretinos-filonazis/>, consulted: 14 April, 2015). In another text, ELTIT coins the phrase "nomadic bodies" to describe subjects who adapt and mutate ideologically to conform to dominant power structures. See, Diamela ELTIT, “Cuerpos nómadas”, in Idem, Emergencias: escritos sobre literatura, arte y política, Santiago de Chile, Planeta/Ariel, 2000, pp. 61-77.

26. ReBolledo, La danza de los cuervos, p. 58.

27. Ibidem, p. 175.

28. Ibidem, p. 216. 
body, therefore, is shot through with the insidious intermingling of power, money, and violence.

Journalist Jorge Escalante, author of the "Prologue" to La danza de los cuervos, correctly affirms that "violence forms the core of Rebolledo's narrative" 29 . Indeed, the reader finds passages that leave him aghast in the face of the perpetrators' brutality and barbarism. The book's lexicon contains words like "corvos" (curved, double-bladed knives for gutting an enemy that were prevalent during the nineteenth-century War of the Pacific and revived by the Pinochet regime) or "empaquetamientos" (the packaging or preparation of bodies to be thrown out of military planes into the sea), all of which become part of a vocabulary that is chillingly naturalized and normalized within a repressive context. The text, moreover, is extraordinarily graphic and direct in its descriptions of the horror that prisoners suffered. Nevertheless, Rebolledo always seems to manage the representation of the morbid with intentionality. Far from wanting to promote a purely voyeuristic or sensationalistic look at the macabre, the journalist seems motivated to reveal what philosopher Giorgio Agamben, following Heidegger, calls the "bureaucratization of horror": an extermination camp that functions like a bureaucratic machine whose goal is to produce cadavers like products on an assembly line ${ }^{30}$.

In any interview, power is volleyed back and forth between interviewer and interviewee. Rebolledo's book is based on more than thirty hours of interviews with Vergara that the journalist frames and manipulates skillfully. At every turn, the Rebolledo mediates Vergara's voice and, because of this, his own intentions take centerstage. And this is precisely as it should be given that, as we know, Vergara's truth has had limits, particularly regarding the period between 1977 and 1985 when, no longer a minor, he continued to carry out functions for the CNI Pinochet's second secret police organization $^{31}$.

Significantly, during all of the episodes that correspond to Vergara's period as El Mocito (1974-1977) Rebolledo integrates Vergara's voice organically in his text, without using quotation marks. This is because everything Vergara claims regarding that period has been well documented by the courts and, for the most part, proven. In contrast, when Vergara refers to his years in the CNI (after 1977), the journalist uses quotation marks as a graphic strategy to take distance from his informant's words and implicitly question the veracity of his discourse. This typographical detail is quite significant because, in the final assessment, Rebolledo approaches his informant skeptically, bringing into relief the ambiguity, the grayness of his status as victim or victimizer. Unwilling to over-humanize him or to aestheticize his redemption, Rebolledo ends his book by emphasizing what Vergara continues to hide. In this sense,

\section{Ibidem, p. 12.}

30 "Before Hannah Arendt, Martin Heidegger, Arendt's teacher in Freiburg in the mid-twenties, had already used the expression 'fabrication of corpses' to define the extermination camps. And, curiously enough, for Heidegger the 'fabrication of corpses' implied, just as for Levi, that it is not possible to speak of death in the case of extermination victims, that they did not truly die, but were rather only pieces produced in the process of an assembly line production.” See Giorgio AGAMBEN, Remnants of Auschwitz: The Witness and the Archive, New York, Zone Books, 1999, p. 73.

31. DINA functioned from 1973 to 1977 . Owing to a series of political pressures, including pressure by international organizations such as Amnesty International and by the United States in the wake of the 1976 Orlando Letelier assassination, DINA was dissolved and replaced by CNI. CNI functioned from 1977 until the end of the dictatorship in 1990. 
the journalist never passes definitive judgment on the moral status of his informant. Instead, he leaves it to the reader to decide how to interpret the ethical grays and silences that glaringly speak through Vergara's discourse and that poetically permeate the book.

\section{Horror for Mass Consumption: The Tomás Mosciatti Interview}

On the night of July 11, 2012, Chile's television audience was once again assaulted by the on-screen image of Jorgelino Vergara, this time interviewed by Chilean journalist Tomás Mosciatti (Chile’s version of Larry King) on his weekly interview program La Entrevista. This program, in general, is known for its thoughtful and hardhitting political commentary, which is reflective of Mosciatti's respected trajectory as a lawyer, journalist, radio personality, and now co-owner of Radio Bío-Bío ${ }^{32}$. Despite this good reputation, however, seated in the studio in a scene that evoked what Argentine critic Leonor Arfuch once called the "performative nature of an interrogation," Mosciatti exposed the popular accomplice and his "truth" to the consumptive eye of the television spectator ${ }^{33}$.

To be blunt, Mosciatti's interview did not add anything new to the debate. Everything had already been said in Rebolledo's book. Furthermore, Mosciatti played the role neither of judge nor detective. His function, plain and simple, was to reveal: to stage what had been said in Rebolledo's book and seize upon its newsworthiness. In that sense, Mosciatti's lengthy interview with Vergara-fifty minutes in total-unfolded like a parade of sound bites taken virtually in chronological order from Rebolledo's book and, in a sense, neutralized the complexities of the character. Subject to the rapidfire pace of the media message, it was clear that the goal of the journalistic mise-enscène was, above all, to jar and shock the audience with the indecent exposure of abjection.

Leigh Payne, in Unsettling Accounts: (2008), points out that media versions of perpetrators' testimonies have a tendency to obliterate the original content of those testimonies ${ }^{34}$. This was certainly the case with Mosciatti's interview of Vergara. In that sense, the first half hour focused on sketching out - yet again - the precarious origins of a strange and pathetic marginalized subject: his impoverished upbringing, the physical and psychological abuse he suffered as a child, his precipitous and happenstance landing in the house of Manuel Contreras. Dressed humbly, much in keeping with the representation he had to give of himself, Vergara spoke slowly and sparsely, carefully measuring his words so as not to incriminate himself or overstep the boundaries of the script he had rehearsed so well. (And this makes sense! After the courts, the film, and the book, he certainly had his script down pat. He had memorized it skillfully.) To round out the scene, Mosciatti likewise acted in front of the cameras. His voice, somber, drawn, dour, masterfully intoned a gravity befitting his subject matter. Suffice it to say that for the first half hour the interview evinced little novelty.

32. Javier Rebolledo invited Mosciatti to present his third book, A la sombra de los cuervos, at Club Providencia, Santiago de Chile, in August 2015. Mosciatti's reading of the phenomenon of civilian complicity with the Chilean dictatorship was well informed and boldly honest.

33. Leonor ARfuCH, El espacio biográfico: dilemas de la subjetividad contemporánea, Buenos Aires, Fondo de Cultura Económica, 2002, p. 124.

34. PAYNE, Unsettling Accounts, p. 23. 
After a commercial break, however, the tenor of the interview changed brusquely. Mosciatti's goal, now, was no longer to highlight the accomplice's humble origins, but to focus on the mechanics of repression within the Simón Bolívar torture center. The macabre and graphic details of repression suddenly took center stage: the gigí (an instrument used to electrocute detainees), the dry submarine, the wet submarine, the packing of cadavers. Nothing was left out of this horrifying account, whose mise-en-scène implored us to recall Nelly Richard's critiques, offered years ago, of the April 11, 1995 Univisión interview of Chile's notorious torturer, Osvaldo Romo $^{35}$. What sense was there in revisiting all of these macabre details that had been well documented by the country's official truth commissions and in myriad other sources? What sense was there in this irresponsible assault on the memories of victims and their families, particularly considering that it was Vergara (the victimizer) who largely controlled the scene? Furthermore, what kind of ethics were at play in this sensationalistic exposé of marginality and horror that left viewers-including me-at once offended and bewitched by a voyeuristic spectacle, a spectacle that made viewers want to turn off the television but, at the same time, compelled them to keep watching?

But perhaps what most stood out in the Mosciatti interview was, again, the power play between Mosciatti and his interviewee - quite different from the power play I referred to in The Dance of the Ravens. This time Mosciatti and Vergara competed for control of the word, each one volleying skillfully, hoping to win the battle. It was apparent that Vergara protected himself at every turn, although at times he risked slipping up:

MOsciatTI: Who were the assassins in that place?

VERGARA: Everyone. Practically.

MOSCIATTI: Everyone killed?

VERGARA: No, not everyone killed, but there was a complicity that practically made (them all/ us all) assassins.

Practically. It is striking that Vergara excludes himself from the ranks of the perpetrators even though, paradoxically, he speaks of a complicity that included everyone. If, in this moment, through a minor slippage in his wording, he almost incriminates himself, immediately thereafter he shields himself from harm, affirming that he never packed bodies, that he only helped to pack them and move them from one point to another.

Regarding his participation in CNI operations after 1977, Vergara denies all involvement and prefers to remain silent. Mosciatti, of course, tries to catch him in a lie by evoking the final sentence of Rebolledo's book, in which Vergara insinuates (in the conditional tense, always hypothetically) that he could have participated in raids on shantytowns in the early 80s that could have resulted in deaths: "Estas son situaciones que se podrían haber dado muchas veces" ("These are situations that could have happened many times”) ${ }^{36}$. In La danza de los cuervos, this hypothetical and conditional answer serves a clear purpose: it opens a door so that the journalist can challenge the veracity and legitimacy of his informant's discourse because he knows that Vergara continues to harbor secrets. In contrast, when Mosciatti confronts Vergara with his prior

35. Nelly RICHARD, “Las confesiones de un torturador y su (abusivo) montaje periodístico”, Revista de crítica cultural, n. 22 (2001), pp. 14-19.

36. ReBOlledo, La danza de los cuervos, p. 275. 
conditional statement, hoping that Vergara will change that conditional to a past tense verb (that is, hoping that he will affirm once and for all, "I participated in raids and killings in shantytowns"), Vergara clings for dear life to the hypothetical nature of his discourse. This, for Mosciatti, is a lost opportunity. The journalist presses his interviewee no further, allowing the accomplice to maintain strict and rigorous control of his speech act. Mosciatti, in other words, misses a key opportunity to force Vergara to elaborate on his protagonism in the shantytown raids of the early 80s; he misses a chance to out him for what he most likely was at that time: a paramilitary operative carefully groomed to kill.

Seated before the cameras of CNN-Chile, then, a marginalized subject, an accomplice, savors his five minutes in the limelight, skillfully toying with the authority figure who, at several points, tries to catch him in a lie. When Mosciatti asks Vergara if he is worried that a judge will investigate his acts during his final years as a CNI agent, Vergara smiles and retorts, "Why? Why should I worry if I'm telling you everything right now?" Only his body language gives him away. He controls his discourse with a vice grip and the smile on his face reveals that he enjoys it.

In the final assessment, even though Vergara's discourse is confessional in nature, it is not really a confession in the strict sense of the term. As Leonor Arfuch notes, confessions, in their Christian version-and, we should remember that Vergara claims to have discovered Christ - lead to an act of repentance and expiation ${ }^{37}$. This is clearly not the end game in Vergara's case:

MOSCIATTI: What are you repentant for? Are you repentant for anything?

VERGARA: No.

MOSCIATTI: Not for anything?

VERGARA: Not for anything. Shall I explain why? What would I gain by repenting at this stage of the game, especially because I didn't become a professional within that system [the secret police] like I wanted to.

This brazen lack of repentance is jarring and makes us call into question the status of victim that has been assigned to Vergara by certain prominent commentators. In the end, there is no doubt that Vergara is a vulnerable subject; nevertheless, there he sits, still harboring the fantasies of an unrepentant wannabe soldier, calling into question at every turn the ethics of his words. The confessional subject exposes himself, yes, but not to the point of handing himself over fully and transparently to the judgment of the public or the authorities.

What, perhaps, would have helped to heal Chile's damaged social fabric forty years on, would have been to hear a repentant voice whose full confession would have truly embraced the philosophy of Never Again. Falling far short of that goal, Mosciatti's abusive journalistic montage did nothing more than recycle a discourse we had already heard years before from General Manuel Contreras himself: that of the military man who felt abandoned and hung out to dry by his cowardly superiors (in Contreras's case, by Pinochet) ${ }^{38}$.

37. Leonor ARfuCH, Crítica cultural entre política y poética, Buenos Aires, Fondo de Cultura Económica, 2008, p. 36.

38. Cherie ZaLAQUETT, "Pinochet nos dejó absolutamente solos. Entrevista a Manuel Contreras”, El Mercurio, 11 September, 2004, <https:/es.groups.yahoo.com/neo/groups/testimonioschile/conversations/messages/3262>, (consulted:14-4-2015). 
In Chile, a series of mea culpa have emerged over the years primarily from the military and some politicians for whom taking responsibility has been more of an instrumental maneuver than a heartfelt action. Discourses that deeply repent and reflect have been virtually nonexistent. If we follow Judith Butler's insights, one can point to an ethical flaw in these types of narratives that attempt to control the presentation of a life and to rationalize actions in ways that very neatly assuage cognitive dissonance in the speaking subject. Although textual control may be a natural tendency for subjects who struggle to find ways to live with themselves, Butler suggests that, to the contrary, "our willingness to become undone in relation to others constitutes our chance of becoming human" ${ }^{39}$. "The account is an act—situated within a larger practice of actsthat one performs for, to, even on another [...]. This account does not have as its goal the establishment of a definitive narrative, but constitutes a linguistic and social occasion for self transformation" 40 and, I would add, for social transformation. If a confessional text is not open to this transformative dimension, if the subject is not willing to become vulnerable through a truly honest reckoning, then the narrative falls short of fulfilling its ethical potential.

The language of the television interview brought no greater understanding of Vergara's experience; in fact, it flattened that experience. The media flash exploited an iconography of Vergara as a popular subject (dressed in a boina and in clothing reflective of his low socioeconomic status) who was sucked into the whirlwind of dictatorial violence and has now seen the light. The interview dwelled on the obscene details of torture and confronted viewers with the abject nature of the lowly lackeys who sometimes carried it out. At the same time, Vergara's brazen lack of repentance and his evasive and power-mongering desire for control made him nothing more than a metonymic stand-in for myriad civilian accomplices - whether weak or powerful-who still fail to recognize or fully acknowledge the role they played in aiding and abetting the Pinochet regime. Perhaps brandishing this lack of repentance in the face of the Chilean public, however vile and distasteful, was the ultimate service that Mosciatti's interview provided for Chile's collective memory. The interview made abundantly clear that for accomplices-as for the right and the military-truth, forty years on, still has firm limits.

\section{Responsibility and Representation}

In a 1964 essay titled "Personal Responsibility Under Dictatorship”, Hannah Arendt offers some ideas that merit consideration. First, in reference to the phenomenon of due obedience (the idea that one was merely following a superior's orders), Arendt observes that "there is no such thing as obedience in moral and political matters" 41. Without ignoring the immense gamut of complicities that authoritarian regimes create, Arendt affirms with conviction that "much would be gained if we managed to eliminate from our moral and political vocabularies that pernicious word 'obedience,",42. According to Arendt, the question that should be posed to the person who collaborated

39. Judith BuTLER, Giving an Account of Oneself, New York, Fordham University Press, 2005, p. 136.

40. Ibidem, p. 130.

41. Hannah ARENDT, Responsibility and Judgment, New York, Schocken Books, 2003, p. 48.

42. Ibidem. 
and obeyed orders is not "why did you obey", but "why did you support" 43 . By way of contrast to Primo Levi, who in "The Gray Zone" writes that the ultimate guilt resides in the totalitarian system itself, Arendt reminds us that guilt and innocence are not functions of a system, but rather only have meaning when they are applied concretely to real individuals in specific cases. ${ }^{44}$. Arendt, in other words, is wary of divesting accomplices of their agency and of attributing guilt to an impersonalized system.

With these contrasting arguments in mind, I find the comments of esteemed Chilean human rights attorney Nelson Caucoto regarding the Mocito case surprising. In an interview that aired on Radio Cooperativa (December 12, 2011), Caucoto, adopting Levi's line of argumentation, stated unequivocally that Vergara was "a victim of his circumstances": "He's a very damaged person, who was damaged by the Chilean state. He could perfectly well apply to the state for a pension [or some kind of reparations] on which to live [that would] help repair the damage that [the state] caused him"45. Caucoto's reading of Vergara interfaces, on some level, with the controversial case of Chile's former military conscripts who, over the last couple of years, have been in the news demanding that the Chilean state pay them reparations for their forced service during the dictatorship. Despite some similarity, however, the case of Jorgelino Vergara seems different to me for two reasons. First, it seems different because it was Vergara's will to be part of the military (he clearly states this many times); and second, because he has made a number of statements (particularly in La danza de los cuervos) in which he appears to have supported the Pinochet regime in ideological terms. It is quite clear based on the evidence, that had Vergara not been relieved of his duties as an agent following a 1985 parachuting accident (during paramilitary training), he likely would have continued as a loyal agent for some time thereafter. It is also clear that if he had felt more valued by his superiors, it is unlikely that he would have sold them out. And finally, if detectives had not hunted him down in 2007 to accuse him of killing Víctor Díaz, he likely would have never broken his longstanding pact of silence with the military.

Certain social, political and economic structures make it possible for subjects like Jorgelino Vergara to exist. Indeed, repressive systems prey on subjects devoid of economic power, on those lacking culture and family support and who hunger for power. It is undeniable that the systems that create subjects such like Vergara also exploit them; but it is equally true that such subjects learn to exploit the very systems that exploit them, and later, fail to claim responsibility for their actions.

Moreover, when Mosciatti or Said try to create points of identification (either sympathy or empathy) between the accomplice and the spectator, they run a tremendous ethical risk. By presenting Vergara as an everyman - a poor guy, down on his luck, who was coopted by the dictatorial state-they run the risk of diluting responsibilities.

\section{Ibidem.}

44. "Before discussing separately the motives that impelled some prisoners to collaborate to some extent with the Lager authorities, however, it is necessary to declare the imprudence of issuing hasty moral judgment on such human cases. Certainly the greatest responsibility lies with the system, the very structure of the totalitarian state; the concurrent guilt on the part of individual big and small collaborators (never likeable, never transparent!) is always difficult to evaluate.” See LEVI, The Drowned and the Saved, p. 44.

45. "Nelson Caucoto: Protagonista de El Mocito también es una víctima”, Radio Cooperativa, 30 March, 2014, <http://www.cooperativa.cl/noticias/pais/dd-hh/nelson-caucoto-protagonista-de-el-mocito-tambienes-una-victima/2011-12-12/132259.html>, (consulted: 6-11-2014). 
Naturalistic or deterministic narratives that seem to say that people necessarily act in evil ways because their circumstances leave them no other option, do not serve us well in analyzing cases like that of Jorgelino Vergara. According to this logic, which displaces guilt onto a system, the category of the victim can become stretched beyond all recognition. Moreover, society becomes susceptible to producing victims retroactively, thus losing sight of who the real victims were.

It has been common in Chile, as of late, for actors of all political stripes to invoke the idea that during a state of exception, "we were all victims." By this logic, even the former president of Chile, the right-wing Sebastián Piñera, can claim, as he has, that he and his wife were almost randomly detained by the military after the coup and, on some level, were also victims. This is simply laughable considering that Piñera, in the 1970s, found himself on the same side of the ideological spectrum as Pinochet and staunchly supported the violent neoliberalization of Chile. By the same token, figures like Piñera (Renovación Nacional) or politicians from the pinochetista UDI party like Senator Hernán Larraín can today distance themselves from Pinochet’s legacy in the interest of political expediency and in the name of a questionable project of national reconciliation. Put another way, the postdictatorship period has had a tendency to produce a generalized notion of victimhood that can dangerously morph to encompass just about any subject position. This is one key danger that lurks behind a vision of Jorgelino Vergara that deemphasizes his personal desires and ideological commitments to a violent counterrevolutionary state. It is my contention that we must never forget his agency. We must never forget that some people did the killing (or aided and abetted it), while other people were killed.

The fortieth anniversary of the September 11, 1973 coup brought with it a glut of media attention that referred ad nauseam to the state terror that plagued Chile for seventeen years. While serious reflections abounded, particularly among a younger generation able to take distance from the events and evaluate them more critically, September 2013 also saw a number of questionable maneuvers that need to be seriously questioned. Many applauded-while others scorned-President Piñera's reference to the "passive accomplices" who helped the dictatorship to thrive, or who turned a blind eye to its violence. But what about the active accomplices who knowingly and willingly made the machinery of terror run? Jorgelino Vergara, of course, is one of those active accomplices. But what about the hundred of others?

Might it be possible that Jorgelino Vergara-an underling, a man of little education and little importance-was the only kind of active accomplice that Chilean society was really willing to see? For Piñera or other elites to admit the active complicity of their own class would have meant a hard look in the mirror that they were not willing to take. On some level, one might argue, then, that Mosciatti's interview and Said's film constructed a marginal figure who metonymically usurped the place of and deflected attention from so many other accomplices-the Mattes, the Kasts, Sergio Onofre Jarpa, Mónica Madariaga, José Piñera Echeñique, Julio Ponce Lerou, Joaquín Lavín, Father Raúl Hasbún, Jovino Novoa, Agustín Edwards, as well as so many other civilians who bear responsibility for the bloodshed. In short, while the $40^{\text {th }}$ anniversary could admit the complicity of the conscripts, Mocitos and passive actors of the world, it was not yet ready to take a long, hard look at the active complicities of a host of sordid figures who still hold tremendous political and economic power.

In closing, what I have referred to in this article as the Mocito phenomenon calls to mind one final danger: the danger that emerges when the archive and its contents migrate towards the realm of the spectacle. As I hope to have shown, a character like 
Jorgelino Vergara lends himself to many readings. If Marcela Said's film de-ideologizes Vergara, takes distance from the accomplice, and seeks to evoke a sympathetic view of him, Javier Rebolledo's book (more responsibly, I think) re-ideologizes him, focusing on the facts as well as the omissions within the accomplice's truth. Rebolledo paints a more ambiguous view of the accomplice-figure that allows readers to question the ethics of his comportment and points more directly to his responsibility in the state's machinery of terror. Tomás Mosciatti's interview, in contrast to both of the other versions, engages in an overt sensationalism of the character, urging a pedagogy of memory (as horror) that leads citizens to consume the past voyeuristically rather than to debate it vigorously or reflect on it productively.

The case of El Mocito invites a reflection on the kinds of complicities upon which the Pinochet regime was built, as well as on the complicities that shaped the subsequent transition to democracy. In a country in which there has been almost no judicial movement toward convicting or trying accomplices of any kind, this debate is more urgent than ever. If the judicial realm is unlikely to be the one in which complicity is tried and made publically visible, cultural production and the court of public opinion become all the more important. It seems to me that the fortieth anniversary of the 1973 coup, which we just marked, has opened a space in which this debate can begin to take place. The question remains, however, regarding how willing Chilean society will be to engage in an honest reckoning with the accomplice within. 